\title{
Project Management Skills in Malaysian Economic Sectors
}

\author{
P. Rukmani a, Kamran Shavarebi b,* \\ a Faculty of Arts \& Science, International University of Malaya-Wales, Kuala Lumpur, Malaysia. \\ ${ }^{\mathrm{b}}$ Faculty of Engineering \& Quantity Surveying, INTI International University Malaysia. \\ *Corresponding author Ph.No : +60176746011; Email: rukh0016@gmail.com \\ DOI: https://doi.org/10.54392/ajir2142 \\ Received: 10-09-2021; Revised: 12-10-2021; Accepted: 14-10-2021 Published: 16-10-2021
}

\begin{abstract}
Objective of this conceptual study is to investigate the demand for project management skills in Malaysian economic sectors and to develop strategies on narrowing down the project management talent gap to enable the nation in leveraging on project management talents to implement strategic initiatives, driving change, and delivering innovation to Malaysia whilst contributing to nation's productivity and standard of living. Previous studies on project management skills demand in Malaysian economic sector is limited, mostly related to non-Malaysian economies and other areas of skills. Demand and supply theory based on Graduate Tracer Study is used as basis to understand and close the gap in project management skills demand and project management talent shortages and, in consideration of potential job mismatch due to traits of workers and the impact of curriculum design on employability competence. This study on project management skills in Malaysia will serve as basis to identify the project management skills gap in Malaysian economic sectors. Proposed model of strategies expected to be developed in this study is aimed to provide granular level insights for government in adopting more targeted approach in meeting the demand for project management skills and narrowing down project management talent shortages.
\end{abstract}

Keywords: Project Management, Skills, Demand, Talents, Malaysia, Strategies.

\section{Introduction}

In recent years demand for Project management is gaining attention from economic sectors to support project management orientated jobs and industries. Demand for competent project management professionals who can manage projects successfully is growing across different industries (Sharma, 2021). Rise in demand for project management skills will benefit project management talents to leverage on this financially rewarding career and their contribution to the nation's GDP (Global Domestic Product), as well as GDP contribution by project orientated industries (PMI, Project Management Job Growth and Talent Gap 2017-2027, 2017). Demand for talents with project management skills and project orientated jobs in Malaysia continue to grow as evidenced in annual COL (Critical occupation List) and Institute of Labor Market Information and Analysis (ILMIA) under the Malaysian Ministry of Human Resources (MOHR).

In 2019, work force in Malaysia accounted for 15.6 million people and overall unemployment rate in 2019 was 3.3\% of the work force (TalentCorp, 2020). This reflects that Malaysia is operating in almost full capacity of its available work force resources with minimal work force available from those unemployed (3.3\%). Developing specific skill such as Project Management in this economy that is performing in almost full capacity is a challenge to Malaysian economic sectors.

COVID 19 pandemic has high youth unemployment and low levels of entrepreneurial activity, as well as the limited potential of young people to work on real life projects because of the COVID-19 economic crisis. Strengthening the entrepreneurial and project management competencies of young people, especially those with high educational potential and ambitions in specialized professional fields, is one of the ways to solve the problem described (Sirec, 2020). 


\section{Current Problem}

Emerging economies like Malaysia that has small working population with low unemployment rate means work force availability is limited and developing specific skills like Project Management in limited work force availability is challenging (Bank, 2019). New technologies, digitization, automation, and other trends like Industry 4.0 demands for project management skills (Bank, 2019).

Demand for project management skills in industries specific such as construction industry (Haron, 2017) and gap between academia and industry demand for hands-on with real world problems relating to project management (Jara, 2019) remains a challenge in other countries as well as Malaysia. Availability of project management talents without project management certification further complicates the determination of project management talent availability (Farashah, 2019).

Application of project management as an essential skill in many industry specifics and diversified jobs (Toreso, 2020) forms part of the rising demand for project management skills globally and locally. Relevance of bridging the gap between academia and industry is achievable through experiential learning or providing students with curriculum that gives them hands-on access to real-world industry research projects that attempt to solve realworld industry issues (Steed, 2013) to enable narrowing down the shortages of project management talents in the economic sectors.

This study will cover project management skills demand based on occupations listed in Malaysian COL (Critical Occupation List) that is published annually in third quarter of the year. Project management talent entering economic sectors on annual basis is obtained through Ministry of Human Resource based on talents who are registered with Higher Education Ministry of Malaysia (MOHE).

Resolving problem of fulfilling project management skills demand by narrowing down the shortages of project management talents in Malaysia will enable Malaysian government to improve policy making on human capital development related to project management talents development through investment in education and training whilst monitoring immigration policies to attract skilled talents in project management field.

\section{A. Related Literatures}

In view of, lack of study available on project management skills demand in Malaysian economic sectors, various past literature review from other countries as well are analysed for this study purposes. Studies conducted by researchers as listed in Table 1 - Related Literature Review, shows the relevance and interest in various countries on demand for project management skills is noteworthy to be studied in Malaysia.

Table 1 Related Literature Review

\begin{tabular}{|l|l|l|l|l|l|}
\hline No & Literature \& Author & Author & Year & Research Area & Country \\
\hline 1 & $\begin{array}{l}\text { Linking humble leadership and } \\
\text { project success; the moderating } \\
\text { role of top management support } \\
\text { and mediation of team building }\end{array}$ & Ali M & 2021 & Technology & Pakistan \\
\hline 2 & $\begin{array}{l}\text { Exploring the value of project } \\
\text { management certification in } \\
\text { selection and recruiting }\end{array}$ & Farashah A D & 2018 & $\begin{array}{l}\text { Project } \\
\text { Management }\end{array}$ & International \\
\hline 3 & $\begin{array}{l}\text { Project management practice and } \\
\text { its effects on project success in } \\
\text { Malaysian construction industry }\end{array}$ & Haron N A & 2017 & Construction & Malaysia \\
\hline 4 & $\begin{array}{l}\text { Skills of junior project } \\
\text { management professionals and } \\
\text { project success achieved by them }\end{array}$ & Hefley W E & 2021 & Business & Brazil \\
\hline
\end{tabular}




\begin{tabular}{|c|c|c|c|c|c|}
\hline 5 & $\begin{array}{l}\text { Status and scope of project } \\
\text { management in the hospitality } \\
\text { industry. }\end{array}$ & Jara E V & 2019 & $\begin{array}{l}\text { Hospitality } \\
\text { Management }\end{array}$ & USA \\
\hline 6 & $\begin{array}{l}\text { Linking "Project Success" and } \\
\text { "Strategic Talent Management": } \\
\text { satisfaction/motivation and } \\
\text { organizational commitment as } \\
\text { mediators }\end{array}$ & Mahjoub M & 2018 & Oil and gas & Iran \\
\hline 7 & $\begin{array}{l}\text { The Demands of Industry } 4.0 \text { on } \\
\text { Project Teams }\end{array}$ & Marnewick C & 2020 & Technology & International \\
\hline 8 & $\begin{array}{l}\text { The effect of curriculum design on } \\
\text { the employability competency of } \\
\text { Malaysian graduates }\end{array}$ & Misni F & 2020 & Management & Malaysia \\
\hline 9 & $\begin{array}{l}\text { Traditional, Agile and Lean Project } \\
\text { Management: A Systematic } \\
\text { Literature Review. }\end{array}$ & Toreso A & 2020 & $\begin{array}{l}\text { Project } \\
\text { Management }\end{array}$ & International \\
\hline 10 & $\begin{array}{l}\text { Job Mismatch and On-the-job } \\
\text { Search Behavior }\end{array}$ & Zakariya Z & 2017 & Management & Malaysia \\
\hline 11 & $\begin{array}{l}\text { Synthesis of Youth } \\
\text { Entrepreneurship and Project } \\
\text { Management competencies for } \\
\text { post COVID-19 challenges }\end{array}$ & Karin Sirec & 2020 & Business & Europe \\
\hline 12 & $\begin{array}{l}\text { Project managers' knowledge } \\
\text { management and competency } \\
\text { model for construction in Malaysia }\end{array}$ & Hashim, E. M. & 2016 & Construction & Malaysia \\
\hline 13 & $\begin{array}{l}\text { Does previous work experience } \\
\text { matter in students' learning in } \\
\text { higher project management } \\
\text { education }\end{array}$ & K K Sharma & 2021 & Construction & India \\
\hline 14 & $\begin{array}{l}\text { Using project demand profiling to } \\
\text { improve the effectiveness and } \\
\text { efficiency of infrastructure } \\
\text { projects }\end{array}$ & Masi J G & 2018 & Infrastructure & UK \\
\hline 15 & $\begin{array}{l}\text { Skills that improve profitability: } \\
\text { The relationship between project } \\
\text { management, IT skills, and small } \\
\text { to medium enterprise profitability }\end{array}$ & Adler J P & 2016 & $\begin{array}{l}\text { Project } \\
\text { management }\end{array}$ & Australia \\
\hline
\end{tabular}

Relevance of secondary data from past literatures in relation to this study provides basis to the rising demand for project management skills that is not only evidenced in Malaysian economy but also globally. The concern on projected growth in demand for project managers and project management competencies, as well as continued growth of new hires moving towards mid-level roles, and continuing difficulties in recruiting sufficient number of project management talents as well as investing in competency development for project managers is expected to deliver increased project success and also to greater retention of those competencies in the organization through less employee turnover (Hefley, 2021). These problems will be studied in detail once the study is started 
Widening gap between actual skills of job seekers and the skills desired by potential employers for project management roles due to variety of industries are increasingly becoming project oriented to achieve their strategic initiatives and remain competitive in this dynamic business environment. As a result, project managers and project team members with the desired project management competencies are vital human resources in national economies across the globe (Sharma, 2021).

Application of project management as an essential skill in many industry specifics and diversified jobs (Toreso, 2020) forms part of the rising demand for project management skills globally and locally.

Relevance of bridging the gap between academia and industry is achievable through experiential learning or providing students with curriculum that gives them hands-on access to real-world industry research projects that attempt to solve real-world industry issues (Steed, 2013) to enable narrowing down the shortages of project management talents in the economic sectors.

Demand for project management skills in local Malaysian economic sectors mainly construction highlights the skills required to apply project management tools in work environment and recommendation to introduce project management training courses in higher education institutions to increase the knowledge of future project management practitioners at early stage (Haron, 2017).

Importance of project management critical competencies such as leadership behaviour contributes to project success (Ali, 2020) are examples of project management skills that project management talents are aspired to achieve in effectively meeting the demand for project management skills.

Adopting measures of professionalism and project management self-efficacy would be excellent additions to the hiring processes, especially for project managers expected to manage highly complex projects and certification is a signaling effort (like advertising commitment to the occupation), rather than a statement about proficiency, encourages practitioners to develop an ongoing professional development program starting with certification and continuing to increase other professional attitudes and attributes (Farashah, 2019).

Strategic talent management is relevant in enabling the ultimate objective of delivering project management talents to economic sectors for the purpose of enabling project success (Mahjoub, 2018) especially in meeting the demands of new technologies, digitization, automation, and other trends like Industry 4.0. New competencies in particular, critical thinking and problem solving are emerging skills identified as well as composition of potential future project teams requiring skills of working along with artificially intelligent robots (Marnewick, 2020)

\section{B. Project Management Skills in Critical Occupation List (COL)}

COL is Malaysia's economic sectors talent shortage list. This is primarily concerned with identifying talent shortages that are associated with growing knowledge-based economy.

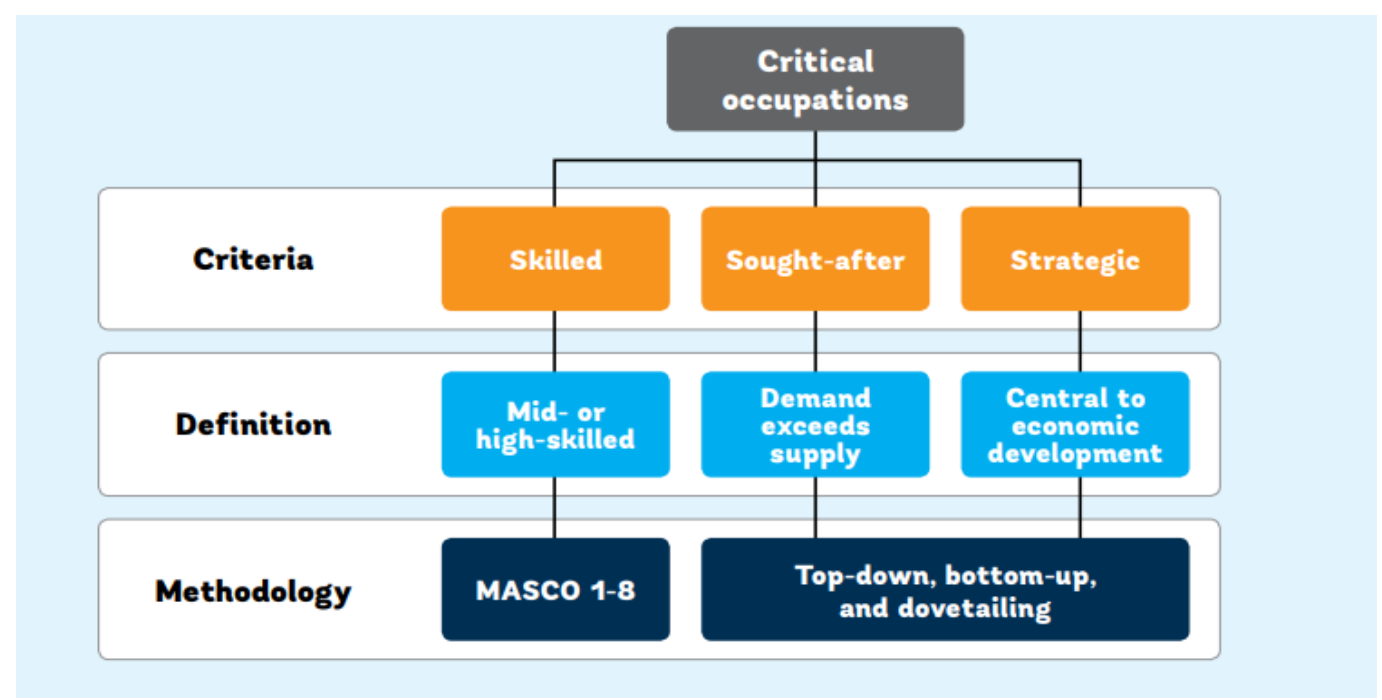

Figure 1 Defining Critical Occupation

Source: (Bank, 2019) 
COL focuses on identifying for occupations that are (mid- or high-) skilled in line with Figure 1 - Defining Critical Occupation that is in accordance with Malaysian Standard Classification of Occupations (MASCO). The COL also determines whether there are mismatches between employers' demand for certain occupations and the supply of skills associated with those occupations.

As a result, the COL seeks to identify shortages that is regarded as demand in occupations requiring respective skills that are sought after by employers. $\mathrm{COL}$ is designed to serve as a tool to help policymakers make decisions. After shortages in skilled occupations are identified, an occupation is considered critical only if filling that occupational shortage is consistent with Malaysia's strategic economic development objectives. In the context of this study on project management skills demand, the COL data will be used to identify occupations that demands for project management skills in economic sectors of Malaysia to perform talent analytics (Cho, 2017)

\section{Project Management Talents}

Talents entering Malaysian economic sectors are obtained from Ministry of Higher Education (MOHE) records of graduates and post-graduates registered with them. Talents covered for this study would represent graduates with project management knowledge and skills that they would have completed in their studies, be it project management as their major study, or some may have covered project management as one of the papers as part of their graduation program.

There are also talents who may have completed additional certifications in project management studies from professional bodies on top of their core studies. Nevertheless, there are many talents without project management knowledge and skills due to their studies that does not include project management as part of their syllabus (Seng, 2018). Project management talents entering Malaysian economic sector is obtained from ILMIA (ILMIA, 2018) and Graduate Tracer Study by MOHE based on registered graduates and post-graduates in Project Management

\section{Conclusion}

Middle income economy like Malaysia with small working population depends very much on labor force availability to increase productivity and to meet the demand in economic sectors. Strategic talent management is relevant in enabling the ultimate objective of delivering project management talents to economic sectors for the purpose of enabling project success especially in meeting the demands of new technologies, digitization, automation, and other trends like Industry 4.0. New competencies in particular, critical thinking and problem solving are emerging skills identified as well as composition of potential future project teams requiring skills of working along with artificially intelligent robots. This study is currently conceptual, and author will do the research to study this problem.

The study on demand for Project Management skills in Malaysia will serve as basis to identify the project management skills gap in Malaysian economic sectors. Proposed strategy model expected to be developed in this study will also provide granular level insights for government especially Ministry of Human Resource to adopt more targeted approach in meeting the demand for project management skill and narrowing down project management talent shortages.

This will be novelty for study on project management skills demand as well as the application of this study to similar future study on project management skills demand related and talent development in global environment and in other fields than project management.

\section{References}

Adler, J.P., (2016), Skills that improve profitability: The relationship between project management, IT skills, and small to medium enterprise profitability, International Journal of Project Management, 34 (5), 831-838. https://doi.org/10.1016/j.ijproman.2016.03.004

Ali, M., Li Z., Khan S., Shah S.J., Ullah R., (2020), Linking humble leadership and project success: the moderating role of top management support with mediation of team-building, International Journal of Managing Projects in Business, 14 (3), 545-562. https://doi.org/10.1108/IJMPB-01-2020-0032 
Bank, W., (2019), Monitoring Cccupational Shortages. Lressons from malaysia's Critical Occupation List, Retrieved from http://documents1.worldbank.org/curated/en/877271568138256963/pdf/Monitoring-OccupationalShortages-Lessons-from-Malaysias-Critical-Occupations-List.pdf

Cho, J.N., (2017), Contribution of talent analytics in change management within project management organizations the case of the French aerospace sector, Procedia Computer Science, 121,625-629. https://doi.org/10.1016/j.procs.2017.11.082

COL, T., (2020), Critical Occupation List 2019/2020. Critical Skills Monitoring Committee.

Farashah, A. D., Thomas J., Blomquist T., (2019), Exploring the value of project management certification in selection and recruiting, International Journal of Project Management, 37(1), 14-26. https://doi.org/10.1016/j.ijproman.2018.09.005

Haron, N. A., Devi P., Hassim S., Alias A.H., Tahir M.M., Harun A.N., (2017), Project management practice and its effects on project success in Malaysian construction industry, IOP Conference Series Materials Science \& Engineering, 2916 . https://doi.org/10.1088/1757-899X/291/1/012008

Hashim, E. M., (2016), Project managers' knowledge management and competency model for construction in Malaysia. Universiti Teknologi Malaysia, $\quad$ Retrieved from http://aunilo.uum.edu.my/Find/Record/my.utm.79282

Hefley, W. E., Bottion M., (2021), Skills of junior project management professionals and project success achieved by them. International Journal of Information Systems and Project Management, 9 (1), 56-75. https://doi.org/10.12821/ijispm090103

ILMIA., (2018), Labour Force Participation Rate (LFPR). Department of Statistics Malaysia. Retrieved Apr, 2021, from Labour Force Participation Rate (LFPR)

Jara, E. V., Babb J.W., Flohr T.M., (2019), Status and scope of project management in the hospitality industry, International Hospitality Review, 33 (2), 142-149. http://dx.doi.org/10.1108/IHR-09-2019-0016

K K Sharma, D. I., Israel D., Bhalla B., (2021), Does previous work experience matter in students' learning in higher project management education?, Engineering, Construction and Architectural Management, 28(1), 424-450. https://doi.org/10.1108/ECAM-01-2019-0015

Mahjoub, M., (2018), national Conference on Project MANagement / HCist - International. Tehran: ScienceDirect. Retrieved from https://pdf.sciencedirectassets.com/280203/1-s2.0-S1877050918X00155/1-s2.0S1877050918317472/main.pdf?X-Amz-Security-

Token=IQ0Jb3JpZ2luX2VjEIL\%2F\%2F\%2F\%2F\%2F\%2F\%2F\%2F\%2F\%2FwEaCXVzLWVhc3QtMSJHMEUCI QD59caebTOP6V9x\%2FSYSh59RdHXD9E\%2Bw7k05k\%2FKeMj\%2FyrQIgYpqk

Marnewick, C., Marnewick A.L., (2020), The Demands of Industry 4.0 on Project Teams, IEEE Transactions on Engineering Management, 67 (3), 941-949. https://doi.org/10.1109/TEM.2019.2899350

Masi, D., Godsell J., Karatzas A., Brady T., (2018), Using project demand profiling to improve the effectiveness and efficiency of infrastructure projects, International Journal of Operations \& Production Management, 38(6), 1422-1442. http://dx.doi.org/10.1108/IJOPM-02-2017-0095

Misni, F., Nik Mahmood N.H., Jamil R., (2020), The effect of curriculum design on the employability competency of Malaysian graduates, Management Science Letters, 10(4) 909-914. http://dx.doi.org/10.5267/j.msl.2019.10.005

MOHR. (2019). Labour Market Dynamics and Future of Work, Cyberjaya: Mid term review, 11MP (MEA). Retrieved from

https://www.ilmia.gov.my/images/newsandevents/PersidanganSumberManusia2019/PEMBENTANG 1.pdf

PMI., (2017), Project Management Job Growth and Talent Gap 2017-2027. Project Management Institute, Retrieved from https://www.pmi.org/learning/careers/job-growth

Seng, L. C., (2018), Malaysian Public University Graduate Employability Policies: An analysis of first degree graduates unemployement and underemployment issues, International Journal of Social Science and Humanities Research, 6(4), 480-489. http://dx.doi.org/10.5281/zenodo.2589702

Sirec, K., Vrečko I., (2020), Synthesis of Youth Entrepreneurship and Project Management Competencies for Post Covid-19 Challenges, 2(1), 684.

Steed E, S. R., (2013), Executive Committee Skills and Completing the Learning Cycle in Hospitality Education, Journal Of Hospitality and Tourism Education, 15(1), 43-51. https://doi.org/10.1080/10963758.2003.10696759 
TalentCorp., (2020), Key Figures 'A QUICK GLANCE AT MALAYSIA'. TalentCorp, Retrieved from https://www.talentcorp.com.my/key-figures

Cruz A., Carvalho Alves A., Tereso A., (2020), Traditional, Agile and Lean Project Management: A Systematic Literature Review, Journal of Modern Project Managemnet, 8(2), 86-95.

Zakariya, Z., (2017), Job Mismatch and On-the-job Search Behavior, Asian Economics Journal, 31(4), 355-379. http://doi.org/10.1111/asej.12135

Does this article screened for similarity: YES

Funding: No funding was received for conducting this study.

Conflict of Interest: The authors have no conflicts of interest to declare that they are relevant to the content of this article.

\section{About The License}

(C) The author(s) 2021. The text of this article is open access and licensed under a Creative Commons Attribution 4.0 International License

\section{Cite this Article}

P. Rukmani, Kamran Shavarebi, Project Management Skills in Malaysian Economic Sectors, Asian Journal of Interdisciplinary Research, 4(4) (2021) 10-16. https://doi.org/10.54392/ajir2142 